\title{
A GORDA DA ILHA DOS AMORES: RESULTADOS SOCIOLÓGIOCOS
}

Prof ${ }^{a}$ Dr. C. M. B. * prefere manter o anonimato devido ao conteúdo que a seguir se expõe.

\begin{abstract}
RESUMO
Um disfarce de conto para publicar o resultado de uma experiência sociológica. Foi a isso que me reduzi. Mas faz sentido. Faz todo o sentido. A experiência deveria ser simples e celebrada. Os resultados deveriam ser os mais inspiradores de uma vida de pesquisas e academicismos. Não foram. Houve só vergonha. E da vergonha brotou a ideia de transformar isso em conto. Não posso ficar com o que me aconteceu. Eu preciso que outros olhos leiam e saibam. Só assim eu expio minha culpa. Só assim eu expurgo essa vergonha. Uma única cópia. Um par de olhos e então o fosso. É disso que preciso. Olhos e fosso. Não me escolham. Não me exponham. Leiam e esqueçam.
\end{abstract}

Se você revelar o que está dentro de você, aquilo que revelar poderá salvá-lo.

Se você não revelar o que está dentro de você, aquilo que não revelar poderá matá-lo.

Evangelho de São Tomé

\section{INTRODUÇÃO}

Começou com a gorda da ilha dos amores. Eu era conferencista convidada e a gorda apresentava um artigo qualquer. Ela não importa. Importa que era gorda. E que além de gorda já não era nova. E, ainda, que não tinha ninguém. Isso se adivinhava logo. Não pela aparência. Adivinhava-se pelos suspiros. Ninguém que alguma vez tenha ido fundo em um relacionamento seria capaz de suspirar daquela forma.

A gorda suspirava inteira enquanto descrevia o amor. Bochechas. Coxas. Orelhas. Tornozelos grossos. Mãos de cozinheira. E os olhos - especialmente os olhos. Ela inteira se transformava na elevação do próprio suspiro.

Era assim: "O amor (suspiro de elevação)... Os sátiros agarrando as ninfas (elevação do suspiro)...". Ela mais suspirava do que falava. Eu percebi no ar: ela supervalorizava o amor. Eu senti dela uma pena excruciante. Comprava tudo que sobre o amor lhe vendiam. Mas não era assim. A realidade não era assim.

Ela falava e suspirava. Eu apenas me perguntava quanto sofrimento ela precisaria acumular até que se tornasse a imagem da amargura. Até que emagrecesse e ganhasse ares de harpia. Lembro-me de ter olhado minhas mãos ossudas. A secura da minha pele. As unhas curtas e cruas de uma mulher madura. Prestei atenção à minha respiração e ela era toda contida. Sem elevações e sem suspiros. Eu contrastava inteira com a gorda. E eu a invejei. Eu queria para mim a inocência. A crença. A esperança. Eu queria ter esse traço que então me lembrei de ter visto nas outras também. Nas solteironas. Esse suspiro permanente de quem acredita. 
Lembrei-me das discussões em um clube do livro. Houve um mês em que a escolha foi particularmente lamentável. Uma história sobre uma solteirona que se apaixona na Toscana. As solteironas todas da roda suspiravam também. Como a gorda. Elas falavam de amor e suspiravam. Elas acreditavam que ainda o encontrariam. Por isso o sucesso do livro. Por isso o sucesso de tanto livro com esse meloso amor. Puro ou mal disfarçado de sexo. Porque é isso que elas querem. As solteironas. E não há alguém para lhes dar.

Ninguém entregaria o coração à gorda da ilha dos amores. Eu sabia. Eu sentia. Sentia no ar que, de tanto ser suspirado por ela, tornava-se rarefeito pra mim. Saí da sala.

Mesmo assim não consegui me livrar dela. A imagem da gorda permaneceu fixada em mim. Foi sem esforço que passei a me sentir como ela. Haveria amor para mim. Haveria. Logo ali. E eu poderia pegá-lo e me fartar dele. Eu poderia sorvê-lo e senti-lo. Experimentar, então, a esperança...

Besteira!

Eu já me tornara racional demais para isso. Mesmo assim... Aquelas palavras e o sentimento que vinha com elas. Aquele ar rarefeito. Aquele suspiro de corpo inteiro. Aquilo me intrigava. Como cientista social eu tive ali um insight.

Maldito insight.

\section{METODOLOGIA DA PESQUISA}

Começou com uma ideia farta e redonda. Quase a arrancar suspiros. Grace Quigley ${ }^{1}$ Eu não podia causar em mim qualquer tipo de paixão. Mas podia providenciar para que causassem. Sem aviso. Sem preparações. Sem parecer algo feito. Grace Quigley! Eu seria como Katharine Hepburn e minha aluna bolsista deveria se virar com as vezes do personagem de Nick Nolte.

Combinei tudo com ela. Expliquei. Fiz com que ela visse o filme. Expliquei de novo. Não falei da gorda da ilha dos amores. E ainda tive tato. Qualquer palavra mal colocada e ela teria a ideia errada. Ressaltei que era uma representação. Uma experiência. Não era de verdade. Ela concordou. Desafiada.

Muito tempo passou. E eu previa que passaria. A bolsista era esperta. Ela precisava da minha distração mais leve. E eu esperava. Esperava por flores de um admirador secreto. Esperava por bombons largados na minha mesa. Esperava por um esbarrão com um estranho e papéis caindo. No entanto esperava sem esperança.

Esperava só porque sabia que era uma experiência e que iniciaria a qualquer momento. Não iniciou. Talvez ela não tivesse entendido. Talvez me faltasse a ousadia de abordá-la de novo.

\footnotetext{
${ }^{1}$ Percebem meu desespero? Aqui cito o filme "Grace Quigley", ou, no original, "The Ultimate Solution of Grace Quigley", em que a personagem título, uma senhora idosa, não encontra coragem para o suicídio e contrata um assassino de aluguel para, sem quem ela saiba quando, matá-la.
} 


\section{REFERENCIAL TEÓRICO}

Um dia entrou na minha sala a viúva do professor de estatística. Olhos pesados. Ainda macerada pela perda. Abracei-a e disse-lhe, mais uma vez, o quanto sentia. Nas mãos dela um livro meu. Eu já até esquecera que o emprestara ao professor. Isso antes. Quando ele ainda era vivo e sorria muito a qualquer um que lhe visse.

Ela me disse, então, com voz baixa que o encontrou na biblioteca do marido. Viu meu nome. Pensou que eu o deveria querer de volta. Peguei o livro das suas mãos. Agradeci. Disse outra vez o quanto lamentava. Ela aquiesceu e se foi.

Três dias depois dei com o livro ainda sobre a minha mesa. Levei-o para sala e fui ocupá-lo na metade da aula.

Da metade do livro caiu um envelope.

Pasmo.

No envelope havia meu nome. Meu nome escrito na letra dura e deitada do professor de estatística. Eu estremeci. Eu pedi licença e saí levando o envelope. Saí da sala e o abri. Dentro dele, as palavras. As palavras que se embaralhavam e dançavam. Eu poderia incluir como anexo $A$ uma cópia da carta. Mas eu a queimei. Depois de lê-la, tornei-me exatamente esse tipo de mulher. O tipo que queima cartas. Isso depois de suspirar, tal como suspirava a gorda da ilha dos amores.

$\mathrm{Na}$ carta de suicídio, eu era o motivo. O professor de estatística escrevera palavras como "amor" e "segredo". "Culpa" e "desejo". "Paixão" ou "morte".

Naquela noite, eu não pude dar a minha aula. Nem nas noites seguintes. Eu não sabia o que sentir. Eu me tornara a gorda da ilha dos amores. A gorda amada enfim. A gorda suspirando por razão. Eu me transformara nas solteironas que tinham encontrado o amor na Toscana. Ao mesmo tempo, eu me fizera de uma Julieta infeliz e desgraçada. Eu me convertera inteira na professora de sociologia amada pelo professor de estatística suicida.

Mas eu sentia. Deus meu, como eu sentia o que eu queria experimentar. Eu amava. Eu tinha em mim a crença. A esperança. A vida. Eu podia entender cada uma daquelas mulheres. Eu podia escrever sobre elas e montar meu artigo. Eu podia dissertar sobre as representações do amor tecidas na solidão. Eu havia, enfim, encarnado uma das suspirosas. A pior. A pior porque meus suspiros eram por um defunto. Eram ares sem volta.

Sim, enquanto vivo, ele me olhava com fogo nos olhos. Só então eu percebia. Ele me sorria de um jeito diferente. Como eu fora burra de não perceber? A mão dele na minha cintura enquanto ele me cumprimentava era quente demais. Como eu não notara?

E o que eu seria se tivesse notado? A vagabunda dele? A amante? Aquela que o roubaria da mulher? A que o encontraria escondido? A que suspiraria satisfeita depois do sexo em um motel qualquer? Exatamente. Era exatamente isso que eu queria ter sido.

E era tarde.

O professor de estatística estava morto. Morto depois de escrever aquelas palavras todas para mim. Morto depois de deixar no meu livro a prova incontestável de que eu era amável. De que ele me preferia à sua esposa de tantos anos. 


\section{CONCLUSÕES}

Eu não conseguia prosseguir. Um homem se matara por mim. Isso era tudo que qualquer mulher podia querer. Não demorou para que notassem a diferença. Para que as alunas se queixassem das aulas. Para que a coordenadoria encaminhasse à reitoria um pedido da minha demissão.

Eu era outra. Nas roupas. Nos modos. No batom vermelho e no esmalte das unhas. Eu descobrira o mistério da gorda e das solteironas. Eu descobrira o que havia por dentro dos suspiros.

E não podia contar.

Mas valia a pena. Jogar fora minha carreira vali a pena. Isso até o dia em que eu recolhia todas minhas coisas dos armários e a bolsista apareceu. Olhos arregalados. Ela queria saber o que aconteceria com ela. Como ficaria o projeto? Como ficaria também a experiência que ela havia iniciado? A carta falsificada escondida no livro... Grace Quigley! Que resultados eu tinha?

*Na verdade, Vinícius Linné, escritor e mestre em Letras, com ênfase em Estudos Literários, pela Universidade de Passo Fundo. Email: vinicius.linne@gmail.com 